\begin{abstract}
Iranica
Abstracta Iranica Revue bibliographique pour le domaine irano-aryen

Volume 32-33 | 2013

Comptes rendus des publications de 2009-2010
\end{abstract}

\title{
Adi Erlich. The Art of Hellenistic Palestine
}

\section{Astrid Nunn}

\section{OpenEdition}

Journals

Édition électronique

URL : http://journals.openedition.org/abstractairanica/40252

DOI : 10.4000/abstractairanica.40252

ISSN : 1961-960X

Éditeur :

CNRS (UMR 7528 Mondes iraniens et indiens), Éditions de l'IFRI

Édition imprimée

Date de publication : 1 décembre 2013

ISSN : 0240-8910

\section{Référence électronique}

Astrid Nunn, «Adi Erlich. The Art of Hellenistic Palestine », Abstracta Iranica [En ligne], Volume 32-33 |

2013, document 61, mis en ligne le, consulté le 26 septembre 2020. URL : http://

journals.openedition.org/abstractairanica/40252 ; DOI : https://doi.org/10.4000/abstractairanica 40252

Ce document a été généré automatiquement le 26 septembre 2020.

Tous droits réservés 


\title{
Adi Erlich. The Art of Hellenistic Palestine
}

\author{
Astrid Nunn
}

\section{RÉFÉRENCE}

Adi Erlich. The Art of Hellenistic Palestine. Oxford, 2009, 136 p., 3 pl. en couleur. (BAR International Series $n^{\circ} 2010$ )

1 L'excellente monographie de A. Erlich traite des arts de la période hellénistique en Israël et englobe les statues de marbre, les statuettes de bronze, les terres cuites, les tombes peintes de Maresha, les mosaïques, les monnaies et les petits objets. Le matériel inédit du site de Maresha constitue le fond de cet ouvrage. Bien que les objets soient évidemment très marqués par l'hellénisme, il est, dans cette publication, souvent question d'objets achéménides encore vénérés ou utilisés à l'époque hellénistique ou porteurs de caractéristiques achéménides qui subsisteront encore un temps (bronzes p. 31-33 ; terres cuites p. 43, 51 et petits objets en faïence p. 99).

\section{AUTEURS}

\section{ASTRID NUNN}

Université de Munich 